\title{
Вплив величини внутрішньочеревного тиску та ішемічно- реперфузіӥних порушень на прояви цитолітичного синдрому та його корекція тіоцетамом в експерименті
}

\begin{abstract}
Мета роботи: з'ясувати вплив ішеміно-реперфузійних порушень на прояви синдрому цитолізу залежно від величини внутрішньочеревного тиску та ефективність корекції виявлених порушень тіоцетамом.

Матеріали і методи. В експерименті використано 90 статевозрілих білих щурів-самців лінії Wistar масою 200-250 г, які знаходилися на стандартному раціоні віварію. Усіх піддослідних тварин наркотизували (тіопентал-натрію 40 мг·кг-1 внутрішньоочеревинно) та моделювали підвищення внутрішньочеревного тиску на 10, 20 і 30 мм рт. ст. шляхом нагнітання в черевну порожнину атмосферного повітря. Час експозиції становив 90 хв, після чого контрольних тварин та тварин кожної дослідної групи відразу виводили з експерименту шляхом тотального кровопускання з серця. Інших тварин кожної дослідної групи (по 6 особин) в умовах анестезії (тіопентал натрію 40 мг·кг-1 внутрішньоочеревинно) виводили з експерименту через 1, 3 і 7 діб після реперфузії. В окремих групах тваринам після реперфузії щоденно протягом 6 діб вводили препарат Тіоцетам (“Галичфарм”, Україна) в дозі 250 мг·кг-1 внутрішньоочеревинно. 3 експерменту їх виводили через 7 діб. У тварин забирали кров, в сироватці якої визначали активність індикаторних ферментів цитолізу аланін- і аспартатамінотрансфераз (АлАТ, АсАТ) уніфікованим методом для аналізатора біохімічного Humalyzer 2000.

Результати досліджень та їх обговорення. Моделювання підвищеного ВЧТ протягом 90 хв супроводжується вираженим цитолітичним синдромом, що проявляється істотним збільшенням активності в сироватці крові АлАТ. Найбільші порушення виникають після реперфузії при величині ВЧТ 20 і 30 мм рт. ст. За цих умов активність АлАТ у сироватці крові зростає ще більше, відмічається підвищення активності АсАТ з максимумом через 3-7 діб. Застосування з корегувальною метою Тіоцетаму в дозі 250 мг·кг-1 внутіршньоочеревинно протягом 6 діб супроводжується вираженим позитивним ефектом, який проявляється істотним зниженням активності АлАТ і АсАТ в сироватці крові при величинах ВЧТ 20 і 30 мм рт. ст.
\end{abstract}

Ключові слова: внутрішньочеревний тиск; ішемічно-реперфузійний синдром; цитоліз, тіоцетам.

Постановка проблеми і аналіз останніх досліджень та публікацій. Одним з грізних ускладнень абдомінальної хірургі є абдомінальний компартмент-синдром (АКС). В його основі лежить підвищення внутрішньочеревного тиску (ВЧТ), зумовлене гострою хірургічною патологією. Різке підвищення тиску в обмеженому просторі призводить до порушення кровообігу, гіпоксії та ішемії розміщених у цьому просторі органів і тканин, сприяючи вираженому зниженню їх функціональної здатності аж до розвитку недостатності [1]. Саме тому летальність при цій патології складає від 10,6 до 68,0 \% і вважається високою [2].

Особливе місце у патогенезі АKC займають функціональні порушення органів шлунково-кишкового тракту. Компресія призводить до порушення мікроциркуляції й тромбоутворення в дрібних судинах, ішемії насамперед кишкової стінки та її набряку з розвитком внутрішньоклітинного ацидозу, що у свою чергу, спричиняє трансудацію й ексудацію рідини та збільшує виразність АКС. Ці порушення маніфестують при підвищенні тиску до 15 мм рт. ст. [3].

Як показали наші попередні експериментальні дослідження, більш виражені метаболічні порушення виникають не тільки в умовах безпосереднього впливу підвищеного ВЧТ, а після наступної реперфузії [4]. Так, реперфузія після 90-хвилинного періоду інтраабдомінальної гіпертензії сприяла більшому зростанню оксидативного стресу і накопиченню вторинних продуктів ліпопероксидації в сироватці крові, печінці та стінці тонкої кишки, який досягав максимуму через 3 доби після реперфузії. За цих умов найбільше показники зростали в печінці, далі у стінці тонкої кишки і крові. Наслідком впливу активних форм кисню і посилення процесів ліпідної пероксидації клітинних мембран є значне зростання їх проникності з розвитком синдрому цитолізу. Однак у доступній літературі ми не знайшли даних про активність процесів цитолізу залежно від величини ВЧТ. Немає даних про ефективність корекції виявлених порушень в умовах АКС комбінованого препарату Тіоцетаму, який володіє комплексним цитопротекторним ефектом, особливо в умовах гіпоксії та ішемії [5].

Мета роботи: з’ясувати вплив ішемічно-реперфузійних порушень на прояви синдрому цитолізу залежно від величини внутрішньочеревного тиску та ефективність корекції виявлених порушень тіоцетамом.

Матеріали і методи. Експерименти проведено на 96 статевозрілих білих щурах-самцях лінії 
Wistar масою 200-250 г, які знаходилися на стандартному раціоні віварію. Через 12 год до експерименту у тварин вилучали їжу, забезпечуючи вільний доступ до води.

Усіх піддослідних тварин наркотизували (тіопентал-натрію 40 мг $\cdot{ }^{-1}$ внутрішньоочеревинно) та в порожнину живота вводили катетер розміром 20 G. У першій дослідній групі (30 тварини) ручним інсуфлятором нагнітали атмосферне повітря до величини ВЧТ 10 мм рт. ст., у другій дослідній групі (30 тварини) - 20 мм рт. ст., у третій дослідній групі (30 тварини) - 30 мм рт. ст. У контрольній групі (6 тварин) повітря не нагнітали. Час експозиції становив 90 хв, після чого контрольних тварин та по 6 тварин кожної дослідної групи відразу виводили з експерименту шляхом тотального кровопускання з серця. Інших тварин кожної дослідної групи (по 6 особин) в умовах анестезії (тіопентал натрію 40 мг· $\Gamma^{-1}$ внутрішньоочеревинно) виводили з експерименту через 1, 3 і 7 діб після періоду підвищеного ВЧТ.

В окремих групах тваринам після декомпресії щоденно протягом 6 діб вводили препарат Тіоцетам (“Галичфарм”, Україна) в дозі 250 мг·кг-1 внутрішньоочеревинно. 3 експерменту їх виводили через 7 діб.

У тварин забирали кров, в сироватці якої визначали активність індикаторних ферментів цитолізу аланін- і аспартатамінотрансфераз (АлАТ, АсAТ) уніфікованим методом для аналізатора біохімічного Humalyzer 2000.

Під час роботи з лабораторними тваринами дотримувались міжнародних вимог про гуманне по- водження з тваринами відповідно до правил “Європейської конвенції захисту хребетних тварин, яких використовують $з$ експериментальною та іншою науковою метою” (European Convention, 1984).

Отримані цифрові дані обробляли статистично. Вірогідність відмінностей між дослідними і контрольною групами оцінювали з використанням програми STATISTICA (“StatSoft, Inc.”, США) на основі непараметричного критерію Манна - Уїтні.

Результати досліджень та їх обговорення. Експерименти показали що внаслідок підвищення ВЧТ у тварин зростала активність у сироватці крові АлАТ і АсАТ, яка залежала від величини ВЧТ. Так, активність АлАТ на висоті ВЧТ 10 мм рт. ст. (табл. 1) практично не збільшувалася порівняно 3 контролем (р>0,05), тоді як після ВЧТ 20 і 30 мм рт.ст. цей показник зростав, відповідно, на 20,1 i 26,3 \% (p<0,05). Проте більші порушення виникали після наступної реперфузії. При величині ВЧТ 10 мм рт. ст. показник досягав максимуму через 1 добу й вірогідно перевищував контрольну групу і вихідний стан $(\mathrm{p}<0,050)$. В подальшому до 7 доби він нормалізувався. При величині ВЧТ 20 мм рт. ст. показник у всі терміни після реперфузії істотно перевищував контрольну групу: через 1 добу - на 83,4 \%, через 3 доби - у 2,33 раза, через 7 діб - у 2,24 раза $(\mathrm{p}<0,05)$. Ще більше активність АлАТ у сироватці крові збільшувалася при величині ВЧТ 30 мм рт. ст., відповідно, у 2,04, 2,74 і 2,96 раза $(\mathrm{p}<0,05)$.

Порівнюючи дослідні групи між собою, встановили, що через 1 добу після реперфузії показ-

Таблиця 1. Активність АлАТ у сироватці крові (ОД·л $\left.{ }^{-1}\right)$ в динаміці реперфузії після внутрішньочеревної гіпертензії різної інтенсивності, (Me (LQ;UQ)) - медіана (нижній і верхній квартилі)

\begin{tabular}{|c|c|c|c|c|c|}
\hline $\begin{array}{c}\text { Величина ВЧТ, } \\
\text { мм рт. ст. }\end{array}$ & Контроль & Вихідний стан & 1 доба & 3 доба & 7 доба \\
\hline 10 & \multirow[t]{3}{*}{$\begin{array}{c}77,8 \\
(68,4 ; 79,8) \\
(n=6)\end{array}$} & $\begin{array}{c}81,1 \\
(75,0 ; 87,0) \\
(n=6)\end{array}$ & $\begin{array}{c}129,5^{*} \\
(115,4 ; 137,5) \\
(n=6)\end{array}$ & $\begin{array}{c}104,9^{*} \\
(101,0 ; 109,7) \\
(n=6)\end{array}$ & $\begin{array}{c}86,3 \\
(77,2 ; 94,9) \\
(n=6) \\
\end{array}$ \\
\hline 20 & & $\begin{array}{c}93,4^{*} \\
(88,0 ; 97,2) \\
(n=6)\end{array}$ & $\begin{array}{c}142,7^{*} \\
(134,5 ; 156,5) \\
(n=6)\end{array}$ & $\begin{array}{c}181,0^{*} \\
(176,0 ; 185,8) \\
(n=6)\end{array}$ & $\begin{array}{c}174,4^{*} \\
(164,8 ; 183,1) \\
(n=6)\end{array}$ \\
\hline 30 & & $\begin{array}{c}98,3^{*} \\
(95,3 ; 104,5) \\
(n=6) \\
\end{array}$ & $\begin{array}{c}158,9^{*} \\
(150,8 ; 167,2) \\
(n=6) \\
\end{array}$ & $\begin{array}{c}213,5^{*} \\
(206,4 ; 221,0 \\
(n=6)\end{array}$ & $\begin{array}{c}230,3^{*} \\
(219,6 ; 243,0) \\
(n=6) \\
\end{array}$ \\
\hline \multicolumn{2}{|c|}{$\mathrm{p}_{1-2}$} & $<0,05$ & $<0,05$ & $<0,05$ & $<0,05$ \\
\hline \multicolumn{2}{|c|}{$\mathrm{P}_{1-3}$} & $<0,05$ & $<0,05$ & $<0,05$ & $<0,05$ \\
\hline \multicolumn{2}{|c|}{$\mathrm{P}_{2-3}$} & $>0,05$ & $>0,05$ & $<0,05$ & $<0,05$ \\
\hline
\end{tabular}

Примітки. Тут і в таблиці 2:

1. * - відмінності стосовно контрольної групи статистично вірогідні $\left({ }^{*}-\mathrm{p}<0,05\right)$.

2. p $_{1-2}$ - вірогідність відмінностей між дослідними групами, в яких моделювали ВЧТ 10 і 20 мм рт. ст.

3. $\mathrm{p}_{1-3}$ - вірогідність відмінностей між дослідними групами, в яких моделювали ВЧТ 10 і 30 мм рт. ст.

4. $\mathrm{p}_{2-3}$ - вірогідність відмінностей між дослідними групами, в яких моделювали ВЧТ 20 і 30 мм рт. ст. 
ник істотно був вищим після ВЧТ 20 і 30 мм рт. ст., порівнняо з 10 мм рт. ст., відповідно, на 10,2 \% $\left(\mathrm{p}_{1-2}<0,05\right)$ і на $22,7 \%\left(\mathrm{p}_{1-3}<0,05\right)$. Через 3 і 7 діб після реперфузії найвищу активність АлАТ у сироватці крові спостерігали при ВЧТ 30 мм рт. ст. далі 20 і 10 мм рт. ст., що виявилося статистично вірогідним $\left(\mathrm{p}_{1-2}<0,05, \mathrm{p}_{1-3}<0,05, \mathrm{p}_{2-3}<0,05\right)$.

Менші порушення були при величині активності АсАТ у сироватці крові (табл. 2). Показник практично не відрізнявся від рівня контролю на висоті підвищеного ВЧТ (р>0,05). При величині ВЧТ 10 мм рт. ст. після реперфузії показник статистично вірогідно зростав тільки через 3 доби й на 11,5 \% перевищував контрольну групу ( $<0,05)$. При величині ВЧТ 20 мм рт. ст. активність АсАТ сироватки крові була істотно вищою від контролю через 1 i 3 доби після реперфузії (відповідно, на 35,6 і 41,5 \%, $\mathrm{p}<0,05)$. Через 7 діб показник знижувався й досягав рівня контрольної групи (р>0,05). При величині ВЧТ 30 мм рт. ст. показник через 1 добу після реперфузії зростав порівняно з контролем на 40,8 \%, через 3 доби - на 59,0 \%, через 7 діб - на 46,3 \% (р<0,05).

Порівняння дослідних груп між собою показало, через 1 добу після реперфузії активність АсАТ в сироватці крові істотно була вища при величині ВЧТ 20 і 30 мм рт. ст. порівняно з 10 мм рт. ст., відповідно, на 30,9 \% ( $\left.\mathrm{p}_{1-2}<0,05\right)$ і 35,9 \%, $\left(\mathrm{p}_{1-3}<0,05\right)$. Через 3 доби після реперфузії величина показника була пропорційно вищою зі зростанням величини ВЧТ $\left(\mathrm{p}_{1-2}<0,05, \mathrm{p}_{1-3}<0,05, \mathrm{p}_{2-3}<0,05\right)$. Через 7 діб після реперфузії показник явно перевищував при величині ВЧТ 30 мм рт. ст., відповідно, на 49,2 \% $\left(\mathrm{p}_{1-3}<0,05\right)$ і на $36,4 \%\left(\mathrm{p}_{2-3}<0,05\right)$.

Таким чином, одним з чинників патогенезу AKC $є$ посилення процесів цитолізу, яке $є$ пропорційним до величини ВЧТ. 90-хвилинне підвищен- ня ВЧТ в білих щурів зумовлює зростання у сироватці крові активності АлАТ, водночас практично не впливає на активність АсАТ. Це пов’язано з органоспецифічністю досліджуваних ферментів цитолізу. АлАТ $є$ переважно печінковим ферментом, тому отримані результати вказують на значний пошкоджувальний вплив підвищеного ВЧТ на печінку. Однак ми вперше в експерименті показали, що найбільші порушення виникають після реперфузії, особливо через 3-7 діб. За цих умов при величині ВЧТ 20 і 30 мм рт. ст. зростає активність і АлАТ і AсAT, що вказує на системний вплив на організм ішемічно-реперфузійного синдрому в умовах реперфузії черевної порожнини. Отриманий нами експериментальний результат підтверджує відоме положення про те, що підвищений внутрішньочеревний тиск негативно впливає не тільки на органи живота, але й на весь організм людини [1].

Застосування Тіоцетаму (рис. 1,2 ) супроводжувалося вираженим позитивним ефектом, який особливо був помітним при величини ВЧТ 20 i 30 мм рт. ст. Так, активність АлАТ після застосування Тіоцетаму при ВЧТ 20 мм рт. ст. знижувалася на $15,2 \%(\mathrm{p}<0,05)$, при ВЧТ 30 мм рт. ст на 28,7 \% (p<0,05). У свою чергу, активність АсАТ при ВЧТ 20 мм рт. ст. внаслідок застосування Тіоцетаму знижувалася на $16,5 \%$ (р<0,05), при ВЧТ 30 мм рт. ст. - на 30,1 \% (p<0,05). Отриманий результат вказує не тільки на гепатопротекторний впив препарату, але й на системний вплив на організм в умовах підвищеного ВЧТ. Подібні дані отримано у роботі окремих авторів при застосуванні інших препаратів 3 ноотропними властивостями [6].

Таким чином, активність маркерних ферментів цитолізу АлАТ і АсАТ сироватці крові відображує ступінь пошкодження внутрішніх органів,

Таблиця 2. Активність АсАТ у сироватці крові (ОД·л-1) в динаміці реперфузії після внутрішньочеревної гіпертензії різної інтенсивності, (Me (LQ;UQ)) - медіана (нижній і верхній квартилі)

\begin{tabular}{|c|c|c|c|c|c|}
\hline $\begin{array}{c}\text { Величина ВЧТ, } \\
\text { мм рт. ст. }\end{array}$ & Контроль & Вихідний стан & 1 доба & 3 доба & 7 доба \\
\hline 10 & \multirow[t]{3}{*}{$\begin{array}{c}113,2 \\
(97,6 ; 124,9) \\
(n=6)\end{array}$} & $\begin{array}{c}113,5 \\
(102,3 ; 124,0) \\
(n=6)\end{array}$ & $\begin{array}{c}117,3 \\
(115,8 ; 121,6) \\
(n=6)\end{array}$ & $\begin{array}{c}126,2^{*} \\
(116,6 ; 134,9) \\
(\mathrm{n}=6)\end{array}$ & $\begin{array}{c}111,0 \\
(103,4 ; 116,2) \\
(n=6)\end{array}$ \\
\hline 20 & & $\begin{array}{c}117,3 \\
(111,2 ; 118,5) \\
(\mathrm{n}=6)\end{array}$ & $\begin{array}{c}153,5^{*} \\
(142,9 ; 159,4) \\
(n=6)\end{array}$ & $\begin{array}{c}160,2^{*} \\
(149,3 ; 164,1) \\
(n=6)\end{array}$ & $\begin{array}{c}121,4 \\
(111,0 ; 128,9) \\
(n=6)\end{array}$ \\
\hline 30 & & $\begin{array}{c}117,0 \\
(113,2 ; 124,6) \\
(n=6)\end{array}$ & $\begin{array}{c}159,4^{*} \\
(145,0 ; 166,2) \\
(n=6)\end{array}$ & $\begin{array}{c}180,0^{*} \\
(169,8 ; 192,2) \\
(\mathrm{n}=6)\end{array}$ & $\begin{array}{c}165,6^{*} \\
(149,1 ; 169,9) \\
(\mathrm{n}=6)\end{array}$ \\
\hline \multicolumn{2}{|c|}{$\frac{1}{\mathrm{p}_{1-2}}$} & $>0,05$ & $<0,05$ & $<0,05$ & $>0,05$ \\
\hline \multicolumn{2}{|c|}{$\mathrm{P}_{1-3}$} & $>0,05$ & $<0,05$ & $<0,05$ & $<0,05$ \\
\hline \multicolumn{2}{|c|}{$\mathrm{P}_{2-3}$} & $>0,05$ & $>0,05$ & $<0,05$ & $<0,05$ \\
\hline
\end{tabular}




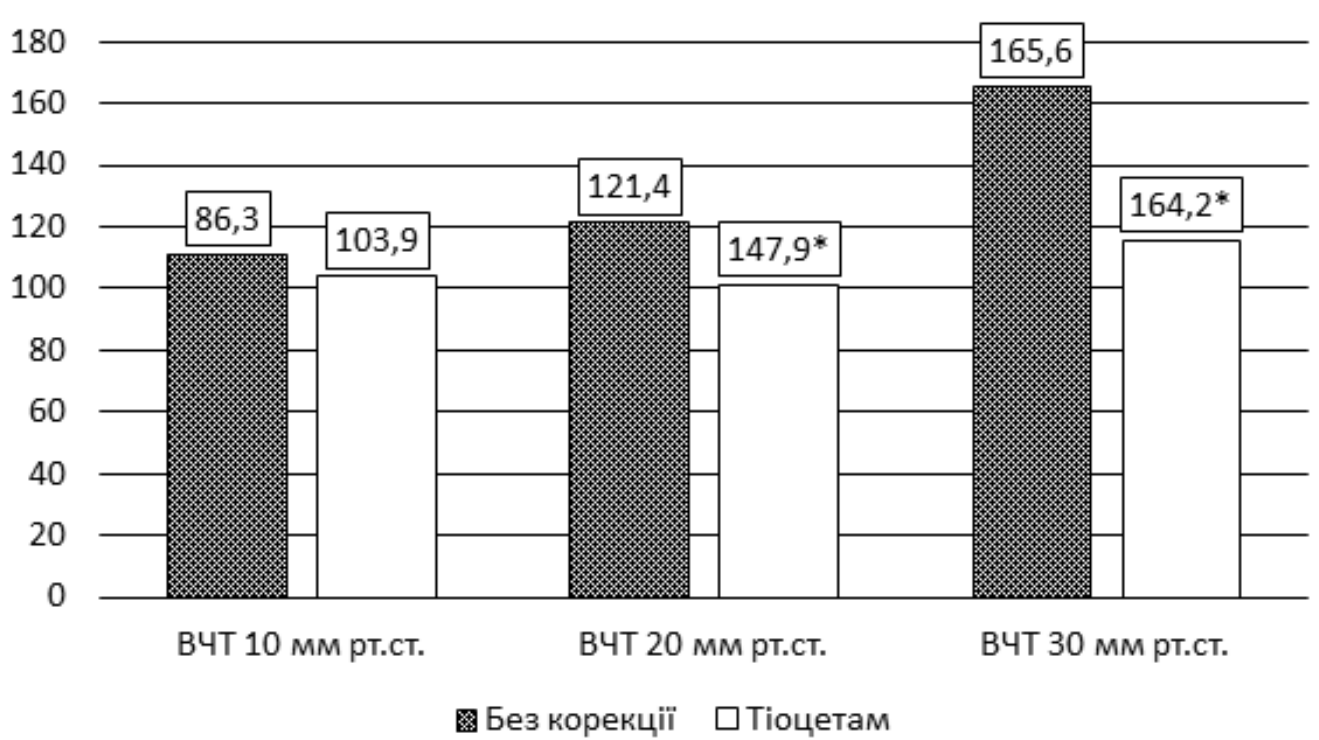

Рис. 1. Активність АлАТ сироватки крові через 7 діб після реперфузії та корекції.

Примітка: тут і на рисунку $2^{*}-\mathrm{P}<0,05$.

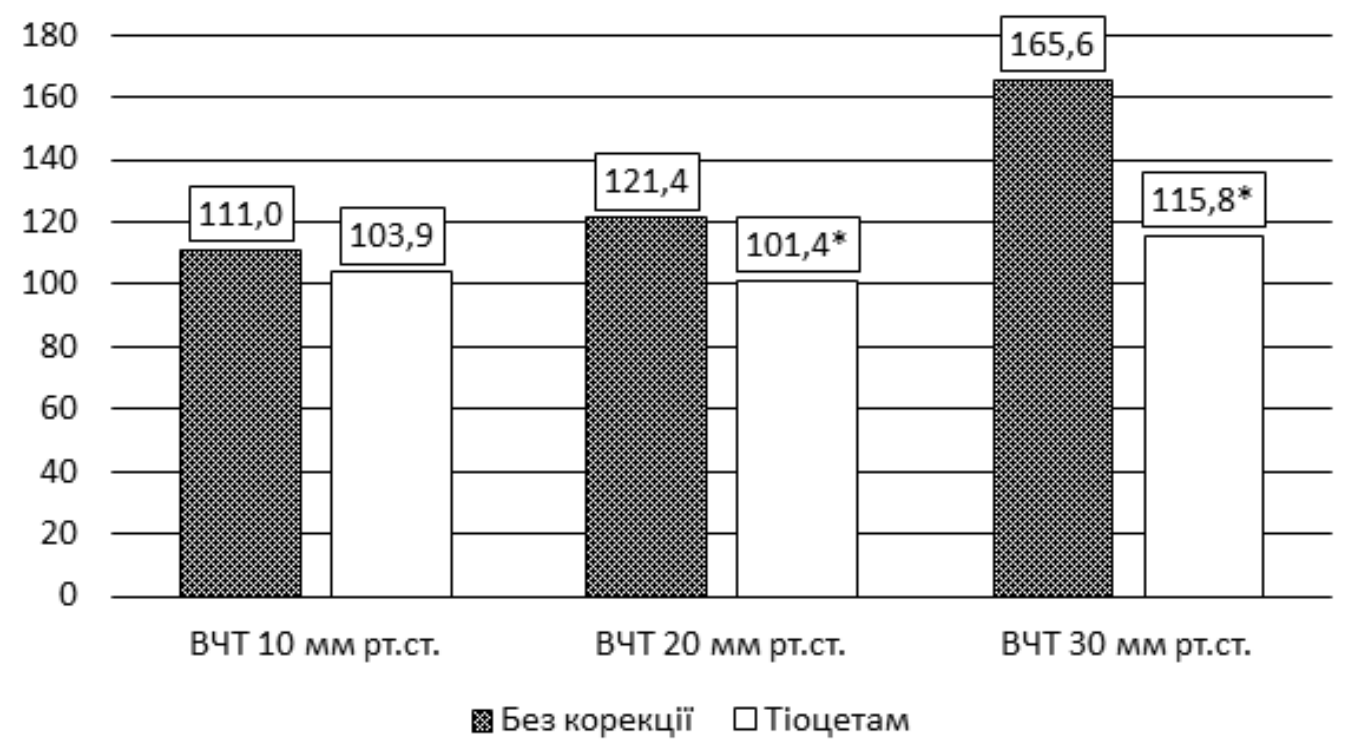

Рис. 2. Активність АсАТ сироватки крові через 7 діб після реперфузії та корекції.

яке пропорційне до величини ВЧТ, й може бути використана як індикатор ефективносіт різних методів корекції.

Висновки. 1. Моделювання підвищеного ВЧТ протягом 90 хв супроводжується вираженим цитолітичним синдромом, що проявляється істотним збільшенням активності в сироватці крові АлАТ.

2. Найбільші порушення виникають після реперфузії при величині ВЧТ 20 і 30 мм рт. ст. За цих умов активність АлАТ у сироватці крові зростає ще більше, спостерігається підвищення активності АсАТ з максимумом через 3-7 діб.
3. Застосування з корегувальною метою Тіоцетаму в дозі 250 мг·кг ${ }^{-1}$ внутіршньоочеревинно протягом 6 діб супроводжується вираженим позитивним ефектом, який проявляється істотним зниженням активності АлАТ і АсАТ у сироватці крові при величнах ВЧТ 20 і 30 мм рт. ст.

Перспективи подальших досліджень. Отримані результати націлюють на розробку засобів профілактики і корекції реперфузійного синдрому в умовах хірургічної декомпресії черевної порожнини та подальшого доклінічного вивчення ефективності Тіоцетаму. 


\section{СПИСОК ЛІТЕРАТУРИ}

1. Гаин Ю. М. Абдоминальный компартмент-синдром / Ю. М. Гаин, В. Г. Богдан, О. В. Попков // Новости хирургии. - 2009. - Т. 28, № 3. - Режим доступу: https://cyberleninka.ru/ article/v/abdominalnyy-kompartment-sindrom-1

2. Синдром интраабдоминальной гипертензии: состояние проблемы / Б. Р. Гельфанд, Д. Н. Проценко, П. В. Подачин [и др.] // Мед. алфавит. неотлож. мед. - 2010. - № 3. - С. 36-43. 3. Рощін Г. Г. Внутрішньочеревний тиск та синдром абдомінальної компресії: питання етіології та патогенезу / Г. Г. Рощін, В. О. Крилюк // Острые и неотложные состояния в практике врача. - 2008. - № 1. - С. 26-27.

4. Мельник О. І. Вплив величини внутрішньочеревного тиску на динаміку ішемічно-реперфузійних порушень в експе-

\section{REFERENCES}

1. Hain, Yu.M., Bogdan, V.G., \& Popkov, O.V. (2009). Abdominalnyy kompartment-sindrom [Abdominal compartment syndrome]. Novosti khirurgii - News of Surgery, 28, 3 Retrieved from: https://cyberleninka.ru/article/v/abdominalnyy-kompartment-sindrom-1 [in Russian].

2. Helfand, B.R., Protsenko, D.N., Podachyn, P.V., Chubchenko, S.V. \& Lapshyna, Y.Yu. (2010). Sindrom intraabdominalnoy gipertenzii: sostoyanie problemy [The syndrome of intra-abdominal hypertension: the state of the problem]. Med. alfavit. neotlozh. med. - Med. Alphabet of Emergency Medicine, 3, 36-43 [in Russian].

3. Roshchin, H.H. \& Kryliuk, V.O. (2008). Vnutrishnocherevnyi tysk ta syndrom abdominalnoi kompresii: pytannia etiolohii ta patohenezu [Intra-abdominal pressure and syndrome of abdominal compression: issues of etiology and pathogenesis]. Ostrye i neotlozhnye sostoyaniya v praktike vracha - Acute and Urgent States in the Practice of a Doctor, 1, 26-27 [in Ukrainian].

4. Melnyk, O.I. (2018). Vplyv velychyny vnutrishnocherevnoho tysku na dynamiku ishemichno-reperfuziinykh porushen v ekspery- рименті / О. I Мельник // Шпитальна хірургія. Журнал імені Л. Я. Ковальчука. - 2018. - № 1. - С. 40-47.

5. Кальчук Р. О. Стравнительная антистрессовая активность комбинированного средства тиоцетам и его составляющих в условиях сочетанного действия воспаления и иммобилизации в эксперимента / Р. О. Кальчук. Л. Т. Киричек // Експериментальна і клінічна медицина. - 2013. - № 2. - C. 42-45.

6. Козак Д. В. Структурні зміни деяких внутрішніх органів тварин із модельованою політравмою за умов корекції карбацетамом / Д. В. Козак, К. С. Волков // Науковий вісник Ужгородського університету. - Серія “Медицина”. - 2014. - Вип. 2 (50). - C. 3-6.

menti [Influence of intraabdominal pressure on the dynamics of ischemic-reperfusion disorders in the experiment]. Shpytalna khirurhiia. Zhurnal imeni L.Ya. Kovalchuka - Hospital Surgery. The Journal named by L. Ya. Kovalchuk, 1, 40-47 [in Ukrainian]. 5. Kalchuk, R.O. \& Kyrychek, L.T. (2013). Sravnitelnaya antistressovaya aktivnost kombinirovannogo sredstva tiotsetam i ego sostavlyayushchykh $\mathrm{v}$ usloviyakh sochetannogo deystviya vospaleniya i immobilizatsii v eksperimenta [Comparative strict antistress actives of the combined agent thiocetam and its constituents under conditions of combined action of inflammation and immobilization in the experiment]. Eksperymentalna i klinichna medytsyna - Experimental and Clinical Medicine, 2, $42-45$ [in Russian]. 6. Kozak, D.V. \& Volkov, K.S. (2014). Strukturni zminy deiakykh vnutrishnikh orhaniv tvaryn iz modelovanoiu politravmoiu za umov korektsii karbatsetamom [Structural changes of some internal organs of animals with simulated polytrauma under conditions of correction of carbacetam]. Naukovyi visnyk Uzhhorodskoho universytetu, seriia "Medytsyna" - Scientific Bulletin of Uzhhorod University, series "Medicine”, 2 (50), 3-6 [in Ukrainian].

\section{O. I. MELNYK}

I. Horbachevsky Ternopil State Medical University

\section{INFLUENCE OF INTRA-ABDOMINAL PRESSURE AND ISCHEMICALLY-REPERFUSIVE LOSSES ON THE MANIFESTATION OF CYTOLYTIC SYNDROME AND ITS CORRECTION BY THIOCETAM IN THE EXPERIMENT}

The aim of the work: to determine the effect of ischemia-reperfusion disorders on the manifestations of cytolysis syndrome depending on the magnitude of intra-abdominal pressure and the effectiveness of correcting the revealed disorders with thiocetam.

Materials and Methods. In the experiment, 90 mature white Wistar male rats weighing 200-250 g were used, which were on a standard ration of the vivarium. All experimental animals were anesthetized (thiopental sodium $40 \mathrm{mg} \bullet \mathrm{kg}^{-1}$ intraperitoneally) and $^{2}$ modeled an increase in intra-abdominal pressure by 10, 20 and $30 \mathrm{~mm} \mathrm{Hg}$ by injecting into the abdominal cavity of atmospheric air. The exposure time was 90 minutes, after which the control animals and animals of each study group were immediately withdrawn from the experiment by total bloodletting from the heart. The other animals of each study group (6 specimens each) under anesthesia (thiopental sodium 40 mg-kg-1 intraperitoneally) were withdrawn from the experiment 1, 3 and 7 days after reperfusion. In individual groups, the animals were injected intraperitoneally with Thioacetam (Galichpharm, Ukraine) daily at a dose of $250 \mathrm{mg}$ kg-1 intraperitoneally after 6 days of reperfusion. From the expert they were taken out after 7 days. The animals were collected blood, in the serum of which the activity of indicator cytolysis enzymes alanine and aspartate aminotransferase (ALT, AST) was determined by a unified method for the biochemical analyzer Humalyzer 2000. 
Results and Discussion. Simulation of increased intra-abdominal pressure for $90 \mathrm{~min}$ is accompanied by a marked cytolytic syndrome, manifested by a significant increase in serum ALT activity. The greatest disturbances occur after reperfusion with a value of increased intra-abdominal pressure of 20 and $30 \mathrm{~mm} \mathrm{Hg}$. In these conditions, the activity of ALT in the blood serum increases even more, there is an increase in ASAT activity with a maximum in 3-7 days. Use with the corrective purpose of thiocetam at a dose of $250 \mathrm{mg} \bullet \mathrm{kg}^{-1}$ intraperitoneally for 6 days is accompanied by a pronounced positive effect, which is manifested by a significant decrease in the activity of ALAT and ASAT in the blood serum with intra-abdominal pressure of 20 and $30 \mathrm{~mm} \mathrm{Hg}$.

Key words: intra-abdominal pressure; ischemic-reperfusion syndrome; cytolysis, thiocetam.

\section{О. И. МЕЛЬНИК}

гВУз “Тернопольский государственный медицинский университет имени И. Я. Горбачевского МЗ Украины”

\section{ВЛИЯНИЕ ВЕЛИЧИНЫ ВНУТРИБРЮШНОГО ДАВЛЕНИЯ И ИШЕМИЧЕСКИ- РЕПЕРФУЗИОННЫХ НАРУШЕНИЙ НА ПРИЗНАКИ ЦИТОЛИТИЧЕСКОГО СИНДРОМА И ЕГО КОРРЕКЦИЯ ТИОЦЕТАМОМ В ЭКСПЕРИМЕНТЕ}

Цель работы: определить влияние ишемически-реперфузионных нарушений на проявления синдрома цитолиза в зависимости от величины внутрибрюшного давления и эффективность коррекции выявленных нарушений тиоцетамом.

Материалы и методи. В эксперименте использовано 90 половозрелых белых крыс-самцов линии Wistar массой 200250 г, которые находились на стандартном рационе вивария. Всех подопытных животных наркотизировали (тиопенталнатрия 40 мг - кг-1 $^{1}$ внутрибрюшинно) и моделировали повышение внутрибрюшного давления на 10, 20 и 30 мм рт. ст. путем нагнетания в брюшную полость атмосферного воздуха. Время экспозиции составлял 90 мин, после чего контрольных животных и животных каждой исследовательской группы сразу выводили из эксперимента путем тотального кровопускания из сердца. Других животных каждой исследовательской группы (по 6 особей) в условиях анестезии (тиопентал-натрия 40 м • кг-1 внутрибрюшинно) выводили из эксперимента через 1, 3 и 7 суток после реперфузии. В отдельных группах животным после реперфузии ежедневно в течение 6 суток вводили препарат Тиоцетам (“Галичфарм”, Украина) в дозе 250 мг•кг-1 внутрибрюшинно. С экспермента их выводили через 7 суток. У животных забирали кровь, в сыворотке которой определяли активность индикаторных ферментов цитолиза аланин- и аспартатаминотрансферазы (АлАТ, АсАТ) унифицированным методом для анализатора биохимического Humalyzer 2000.

Результаты исследований и их обсуждение. Моделирование повышенного ВБД в течение 90 мин сопровождается выраженным цитолитическим синдромом, проявляется существенным увеличением активности в сыворотке крови АлАТ. Наибольшие нарушения возникают после реперфузии при величине ВБД 20 и 30 мм рт. ст. В этих условиях активность АлАТ в сыворотке крови возрастает еще больше, отмечается повышение активности АсАТ с максимумом через 3-7 суток. Применение с коррекционной целью Тиоцетама в дозе 250 мг ${ }^{\bullet} \mathrm{K}^{-1}$ внутрибрюшинно в течение 6 суток сопровождается выраженным положительным эффектом, который проявляется существенным снижением активности АлАТ и АсАТ в сыворотке крови при ВБД 20 и 30 мм рт. ст.

Ключевые слова: внутрибрюшное давление; ишемически-реперфузионный синдром; цитолиз, тиоцетам. 